\title{
Another explanation for the low allergy rate in the rural Alpine foothills Matthias Wjst*
}

\author{
Address: Institut für Epidemiologie GSF - Forschungszentrum für Umwelt und Gesundheit Ingolstädter Landstrasse 1 D-85758 Neuherberg / \\ Munich Germany \\ Email: Matthias Wjst* - m@wjst.de \\ * Corresponding author
}

Published: 05 June 2005

Clinical and Molecular Allergy 2005, 3:7 doi: I0.1 I86/1476-796I-3-7
Received: 25 January 2005

Accepted: 05 June 2005

This article is available from: http://www.clinicalmolecularallergy.com/content/3/1/7

(c) 2005 Wjst; licensee BioMed Central Ltd.

This is an Open Access article distributed under the terms of the Creative Commons Attribution License (http://creativecommons.org/licenses/by/2.0), which permits unrestricted use, distribution, and reproduction in any medium, provided the original work is properly cited.

\begin{abstract}
A low allergy rate in coal and wood heated homes has been described in the small villages in the Alpine foothills and subsequently found to be associated with the farming environment. This was interpreted within the framework of the hygiene hypothesis but there are also alternative explanations. Lower air pollution could be one reason, which is, however, unlikely since the differences between the Bavarian countryside and the Munich municipal area were only weak. There could be genetic differences between the urban and rural population by previous isolation or by self-selection. The potential drop-out of allergy genes, however, will also not explain the absent increase of allergies in two generations. More likely, other lifestyle factors are important. Dietary habits are different in farmers and a less frequent vitamin $D$ supplementation of newborns (otherwise expected to be allergy promoting) has been shown recently. The underlying cause for the "non-allergic farm child" remains speculative until the transfer of any farm-associated factor is leading to a similar risk reduction in the general population.
\end{abstract}

\section{Introduction}

Allergy prevalence has been on the rise worldwide and nearly hundred years after coining "Allergie" in the "Münchner Medizinische Wochenschrift" [1] the causal risk factors are still unknown.

At the end of the 1980s, air pollution related effects were thought to be responsible for the allergy epidemic. It turned out, however, that at least traffic related combustion was not the main culprit in the Munich municipal area, neither based on the inner city distribution of pollutants [2] nor by comparison with a control region in Upper Bavaria. In this study, located in the South of Munich on the Alpine foothills, I examined nearly two thousand fourth-grade children between October 1989 and July 1990 in more than 50 villages. I already noted at that time a relationship between the farm odour in some of the small classrooms and the nearly absence of any positive skin prick test (the "Ostallgäu" phenomenon). A protective effect of coal heating was eventually published six years later [3] but received little attention as the public interest focused mainly on East- and West German air pollution differences [4]. It was only in 1999 where a long series of studies in the farming environment started [5-12] which lead to the current version of the hygiene hypothesis that allergy develops where the natural high endotoxin level on farms is absent. Endotoxin has already been described in a study in 2000 as the main component protecting against allergic sensitisation [13]. 


\section{Problems with the hygiene hypothesis}

The hygiene hypothesis is based on the the initial observation of "unhygienic" siblings by Golding and Peters 1986 [14]. After more than one decade of research [15], however, Strachan concluded that "an inverse association between infection and allergy has not been confirmed directly by epidemiological studies. The available data are either inconsistent or inconclusive" [16]. This view is supported by several other authors [17-19] as the adaptive immune system "with an array of potential interactions .... is reduced to a single level" [20]. Although even a patent has been filed on components of stable air to treat allergy [21], a task force of the European Academy of Allergology and Clinical Immunology (EAACI) arrived at the opinion that "there is no recently published evidence in favour of a clinical use of so-called bacterial extracts against asthma and allergic diseases." [22]

During the discussion of factors related to hygiene it seemed to be largely neglected, that (viral) infection may even enhance allergic disease [23]. Also the inverse association of hepatitis antibodies and allergy found in Italian military students [24] has not been reproduced in consecutive studies [25-27]. The protection against allergic disease by mycobacteria [29] could also not be reproduced in the following dozen studies [28]. The support for the hygiene hypothesis therefore remains weak.

Unfortunately, all farming studies are based on observational and retrospective data given rise to concerns not mentioned in previous reviews [30,31]. The transition of a farming society into the industrial age neither coincides with the main peak of the allergy prevalence in Western countries nor does it match the geographical distribution of the disease.

\section{Is endotoxin to blame?}

Although there are well-designed studies describing the immunological action of endotoxin [32-35] there are no quantitative data in humans how the nanogram exposure on the pulmonary epithelium will supersede the gramwise exposure on the gut mucosa. The number of bacteria on the human body's surface is more than 10 times greater than all his somatic cells [36]. Even if N-acetyl-muramic acid is found to be significantly higher in dust from farm children's mattresses $(+20 \%$ [37]) or endotoxin units are being increased $(+66 \%[10])$, is is unclear whether this has any biological meaning [38]. There are many reasons why dust deposition on the floor may not be equal to effective exposure as this involves inhalation, deposition, uptake, processing, preservation and target delivery. In the only study available so far, both asthmatic and non asthmatic probands had the same LPS concentrations in their bronchoalveolar lavage [39].
Even if we assume a relevant target exposure, there are effective mechanism to counteract endotoxin $[40,41]$. Dose and timing [42], even the origin from different bacteria $[43,44]$ as well as host characteristics $[38,45]$ are being important. Lipopolysaccharides from some bacteria may induce even a Th2 type response [44] where the induction of sensitization is an allergen-specific phenomenon that can not be simply attributed to endotoxin [46]. Epidemiological effects of LPS in dust are often found with extremes of the distribution only, either not significant [47], marginally significant $[13,6,48-50]$, non-linear [10], heterogeneous [51] or even in the opposite direction [52-54].

The main contradiction [55], however, stems from the fact that farming is a frequent risk factor for allergy [56] and asthma $[57,58]$. This might be the explanation why some studies do not find any association between farming and sensitization $[59,60]$ or even opposite results [61].

Research into the biology of endotoxin had many unexpected turns and "has engendered immense curiosity over the years" according to one of its pioneers $[41,62]$. "Why should diminished exposure to microrganism result in inadequate priming of T regulatory cells?" [63]. Any different LPS exposure effect in early life than later on as suggested by Martinez [64] is contradicted by studies where inhalation of LPS induces airway inflammatory response and wheezing [65-69]. This airway response was dosedependent in both, healthy and asthmatic subjects [65], genetically determined [70-72] and may be enhanced by concomitant inhalation of allergen challenge [73]. It is therefore not unexpected that endotoxin exposure is still the main determinant of lung function decline in farmers $[74,75]$.

\section{Are other bacterial components relevant?}

With the ubiquitous occurrence of LPS, its association also to non-farm settings [10], or other household factors $[76,77]$ the situation is far from being clear. There might be effects by other bacterial products $[37,78]$ but there are even considerable doubts if bacterial co-factors are responsible for the observed effects. The largest study concluded that "environmental changes affecting the whole of society have promoted an increase in asthma, allergic rhinitis and eczema in both farming and non-farming environments ... whereas the protective effect of growing up on a farm on the risk of asthma appears to be a fairly recent phenomenon" [79]. Similar conclusions are reported in the second largest study where "the percentage of subjects with symptoms of rhinitis or allergic sensitization was generally lower in subjects who had lived on a farm than in other subjects but the difference was significant only in subjects born after 1961" [80]. In addition also a study from Switzerland reported only a very recent 
increase of allergy in children from non-farming households [7]. If we assume that the bacterial universe did not undergo a major change since 1961, direct bateria-related effects are not very likely.

\section{What else could explain the "non-allergic farm child" effect?}

Lower air pollution by industry or car traffic could be one reason. Unfortunately, this explanation is rather unlikely as the absolute difference between the Upper Bavarian countryside and the Munich municipal area was weak [3].

Second, there might be a self-selection mechanism leading to the drop-out of allergic people, otherwise known in epidemiology as "healthy worker" effect. This phenomenon can hardly explain the absent increase of allergies during the last generation [80].

As there is a clear genetic influence on the development of allergy $[81,82]$ there might be different genes and variants in farmers due to previous isolation. This may be assumed from the unexpected finding of longer linkage disequilibrium blocks in a recent comparison of rural and urban communities [83]. Again, this observation does not explain the recent generational increase although we have argued earlier that the reduction of newborn respiratory mortality by antibiotics may have changed our gene pool [84]. Also other environmental exposure may influence the gene pool. It could be shown recently that elevated levels of folic acid during the periconceptional period could select human embryos that carry a mutant MTHFR allele (with adverse effect on later vascular disease) [85]. Any differential exposure in farmers might therefore be important on their particular genetic background.

Fourth, the socioeconomic situation in the Alpine farmers is different compared to the major cities. There might be a lower vaccination rate although there is no evidence that early vaccination can cause later allergy [86-90]. Farmer might use less antibiotics (an effect under extensive research [87,91-94]), however, the antibiotic level in farm dust has been reported to be high [95]. In one study farm children had more siblings, were more likely to be breastfed and to have pets [96]. In another study farm children had again more siblings, were more likely to have a cat or $\mathrm{dog}$, to experience more serious respiratory infections and less likely to have attended daycare [80]. A higher number of siblings is in favour of the traditional hygiene hypothesis [15] but adjustment for family size did not resolve the farming effect. Less daycare attendance even argues against the hygiene hypothesis $[97,98]$.

\section{Do dietary factors play a role?}

Finally, food and dietary habits may be different in farmers. For example farmers use less aggressive vitamin sup-

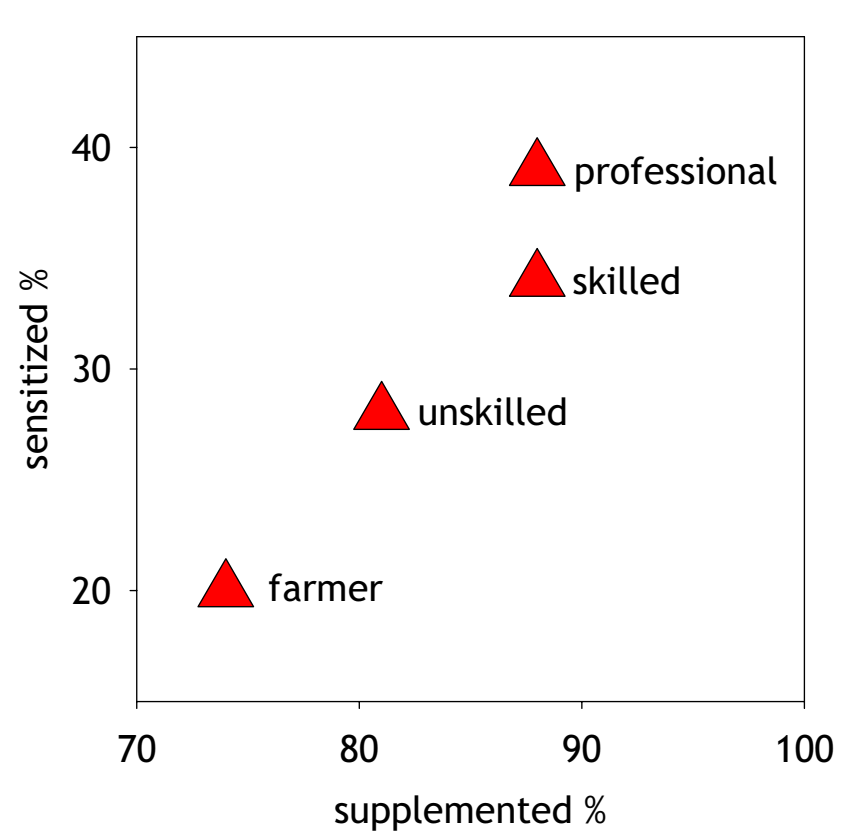

Figure I

The figure is adapted and drawn from a previous study reported in reference [99]. Included are 10,821 individuals of a Finnish birth cohort, where the percent of individuals with intake of the recommended vitamin $D$ supplementation of 50 $\mu \mathrm{g} /$ day $(2000 \mathrm{IU})$ recorded at the first birthday follow-up in 1967) is plotted against the percent of individuals sensitized against cat, birch, timothy grass or house dust mite at age 31 by profession.

plements (Figure 1, [99]). This observation may be important as vitamin $\mathrm{D}$ is widely used in the newborn period to prevent rickets [100] although its main metabolite is known to suppresses dendritic cell function resulting in the inability to mount a sufficient Th1 response [101]. Animal [102,103], genetic [104-106] and epidemiological studies $[99,107]$ now support a role in the development of allergy.

This seems to be particular important as the "non-allergic farm child" effect is observed preferentially in a region only after the general introduction of vitamin D supplementation. The upsurge in allergy and asthma prevalence has been identified as a "post-1960s"-epidemic [80,108] which matches exactly with the time point of a general rickets prophylaxis approach in Bavaria [109]. Furthermore, the farm protection was seen mainly found during the first year of life $[30,110]$ where vitamin D supplementation period is now recommended in Bavaria $[111,112]$. 
Farmers consume more local foods and less supplements. The protective effect of farm milk could relate to the avoidance of otherwise fortified milk from supermarkets [113]. Although milk is usually not fortified in the Alpine region, nearly all baby foods contain vitamin supplements. An alternative food related hypothesis has been setup for Crohns' disease [114] where the transition of cold food storage could be leading to different bacterial exposure.

\section{Body height and head circumference, further pieces in the puzzle?}

There is also another unpublished observation from our first study 1989 in Upper Bavaria where remote village size was not only associated with less allergic rhinitis but also with decreased body height. An increase in body height is a known effect of vitamin D treatment [115119]. In a Norwegian study, male farmers were on average $2,3 \mathrm{~cm}$ and female famers $1,4 \mathrm{~cm}$ smaller (personal communication E. Omenaas 2005 [120]). A more recent German study [121] showed birth weight to be positively associated with later allergic sensitization while in British babies the head circumference was associated with the development of high IgE levels [122-125]. Do vitamin D supplements explain this association?

\section{Relationship between hygiene and vitamin hypothesis}

Both, vitamin and hygiene hypotheses are not mutually exclusive. For example there has been a higher frequency of respiratory infections in vitamin D deficient children [126-129], a phenomenon also found in farming children [80]. On a cellular level it is being known that calcitriol pulsed dendritic cells show a blunted response to LPS $[130,131]$, where LPS pulsed IL-12 response $[13,132]$ can override the otherwise blocking effect of calcitriol (giving possibly farming children a higher capacity to tolerate external vitamin $\mathrm{D}$ doses). Similar results have been obtained in human monocytic cells where LPS downregulated vitamin D receptor levels and thus inhibited vitamin D action [133].

\section{Conclusion}

Many of the clinical and epidemiological observations in the farming populations are neither conclusive nor fully understood. Will further studies in the rural Alpine foothills provide the final answer?

\section{Competing interests}

The author(s) declare that they have no competing interests.

\section{Authors' contributions}

The author developed the hypothesis presented here, conducted the literature survey, wrote the paper and approved the final version of the manuscript.

\section{Funders}

My salary is paid by GSF FE 73922.

\section{Acknowledgements}

None.

\section{References}

I. Pirquet : Allergie, Münchn Med Wschr 1906, 53:1457.

2. Wjst M, Reitmeir P, Dold S, Wulff A, Nicolai T, von Loeffelholz-Colberg EF, von Mutius E: Road traffic and adverse effects on respiratory health in children. Bmj 1993, 307:596-600.

3. von Mutius E, Illi S, Nicolai T, Martinez FD: Relation of indoor heating with asthma, allergic sensitisation, and bronchial responsiveness: survey of children in south Bavaria. Bmj 1996 3 I 2: |448-1450

4. von Mutius E Martinez FD, Fritzsch $C$, Nicolai T, Roell G, Thiemann $\mathrm{HH}$ : Prevalence of asthma and atopy in two areas of West and East Germany. Am J Respir Crit Care Med I994, I 49:358-364.

5. Braun-Fahrlander C, Gassner M, Grize L, Neu U, Sennhauser FH, Varonier HS, Vuille JC, Wuthrich B: Prevalence of hay fever and allergic sensitization in farmer's children and their peers living in the same rural community. SCARPOL team. Swiss Study on Childhood Allergy and Respiratory Symptoms with Respect to Air Pollution. Clin Exp Allergy 1999, 29:28-34.

6. Von Ehrenstein OS, Von Mutius E, Illi S, Baumann L, Bohm O, von Kries R: Reduced risk of hay fever and asthma among children of farmers. Clin Exp Allergy 2000, 30:187-193.

7. Gassner-Bachmann M, Wuthrich B: [Farmers' children suffer less from hay fever and asthma]. Dtsch Med Wochenschr 2000 , | 25:924-93|.

8. Riedler J, Braun-Fahrlander C, Eder W, Schreuer M, Waser M, Maisch S, Carr D, Schierl R, Nowak D, von Mutius E: Exposure to farming in early life and development of asthma and allergy: a crosssectional survey. Lancet 200I, 358: I I29-II33.

9. Kilpelainen $M$, Terho EO, Helenius $H$, Koskenvuo $M$ : Childhood farm environment and asthma and sensitization in young adulthood. Allergy 2002, 57: I I30-। I35

10. Braun-Fahrlander C, Riedler J, Herz U, Eder W, Waser M, Grize L, Maisch S, Carr D, Gerlach F, Bufe A, Lauener RP, Schierl R, Renz H, Nowak D, von Mutius E: Environmental exposure to endotoxin and its relation to asthma in school-age children. N Engl J Med 2002, 347:869-877.

II. Horak FJ, Studnicka M, Gartner C, Veiter A, Tauber E, Urbanek R, Frischer T: Parental farming protects children against atopy: longitudinal evidence involving skin prick tests. Clin Exp Allergy 2002, 32: II55-।1159.

12. Portengen L, Sigsgaard T, Omland O, Hjort C, Heederik D, Doekes $\mathrm{G}$ : Low prevalence of atopy in young Danish farmers and farming students born and raised on a farm. Clin Exp Allergy 2002, 32:247-253.

13. Gereda JE, Leung DY, Thatayatikom A, Streib JE, Price MR, Klinnert $M D$, Liu AH: Relation between house-dust endotoxin exposure, type I T-cell development, and allergen sensitisation in infants at high risk of asthma. Lancet 2000, 355: I 680-I683.

14. Golding JPT: Eczema and hay fever. Butler NR, Golding J, eds From Birth to Five A Study of the Health and Behaviour of Britain's 5-Year-Olds Oxford: Pergamon Press 1986:171-186.

I5. Strachan DP: Hay fever, hygiene, and household size. Bmj 1989, 299: $1259-1260$

16. Strachan DP: Family size, infection and atopy: the first decade of the "hygiene hypothesis". Thorax 2000, 55 Suppl I:S2-I0.

17. Platts-Mills TA: Asthma Severity and Prevalence: An Ongoing Interaction between Exposure, Hygiene, and Lifestyle. PLoS Med 2005, 2:122-126.

18. Flohr C, Pascoe D, Williams HC: Atopic dermatitis and the 'hygiene hypothesis': too clean to be true? Br J Dermatol 2005, I 52:202-216. 
19. Forastiere F, Sunyer J, Farchi S, Corbo G, Pistelli R, Baldacci S, Simoni M, Agabiti N, Perucci CA, Viegi G: Number of offspring and maternal allergy. Allergy 2005, 60:510-514.

20. Maziak $W$ : The asthma epidemic and our artificial habitats. BMC Pulm Med 2005, 5:5.

21. Mutius von E, Braun-Fahrlaender C, Nowak D, Riedler J: Composition containing bacterial antigens, used for the prophylaxis and the treatment of allergic diseases. European Patent Office; WO0 I 493/9; $\quad$ http://v3.espacenet.com/textdoc?DB=EPO $D O C \& I D X=W O 0 \mid 493 / 9 \& F=0 \& Q P N=W O 0 / 493 / 9 \& R P N=W O 01493$ 19\&DOC $=$ deb45b02a960 I8d3934d05c58d45ecbc84 $200 \mathrm{I}$.

22. Matricardi PM, Bjorksten B, Bonini S, Bousquet J, Djukanovic R, Dreborg S, Gereda J, Malling HJ, Popov T, Raz E, Renz H, Wold A: Microbial products in allergy prevention and therapy. Allergy 2003, 58:46I-47I.

23. Dahl ME, Dabbagh K, Liggitt D, Kim S, Lewis DB: Viral-induced T helper type I responses enhance allergic disease by effects on lung dendritic cells. Nat Immunol 2004, 5:337-343.

24. Matricardi PM, Rosmini F, Ferrigno L, Nisini R, Rapicetta M, Chionne P, Stroffolini T, Pasquini P, D'Amelio R: Cross sectional retrospective study of prevalence of atopy among Italian military students with antibodies against hepatitis A virus. Bmj 1997 31 4:999-1003.

25. Uter W, Stock C, Pfahlberg A, Guillen-Grima F, Aguinaga-Ontoso I, Brun-Sandiumenge $C$, Kramer A: Association between infections and signs and symptoms of 'atopic' hypersensitivity--results of a cross-sectional survey among first-year university students in Germany and Spain. Allergy 2003, 58:580-584.

26. Jarvis D, Luczynska C, Chinn S, Burney P: The association of hepatitis $A$ and Helicobacter pylori with sensitization to common allergens, asthma and hay fever in a population of young British adults. Allergy 2004, 59:1063-1067.

27. Gonzalez-Quintela A, Gude F, Boquete O, Aguilera A, Rey J, Meijide LM, Fernandez-Merino MC, Vidal C: Association of hepatitis A virus infection with allergic sensitization in a population with high prevalence of hepatitis A virus exposure. Allergy 2005, 60:98-103.

28. Shirakawa T, Enomoto T, Shimazu S, Hopkin JM: The inverse association between tuberculin responses and atopic disorder. Science 1997, 275:77-79.

29. Matricardi PM, Yazdanbakhsh M: Mycobacteria and atopy, 6 years later: a fascinating, still unfinished, business. Clin Exp Allergy 2003, 33:717-720.

30. von Mutius $E$ : Influences in allergy: epidemiology and the environment. I Allergy Clin Immunol 2004, I I 3:373-9; quiz 380

31. Kabesch M, Lauener RP: Why Old McDonald had a farm but no allergies: genes, environments, and the hygiene hypothesis. J Leukoc Biol 2004, 75:383-387.

32. Gerhold K, Bluemchen K, Franke A, Stock P, Hamelmann E: Exposure to endotoxin and allergen in early life and its effect on allergen sensitization in mice. J Allergy Clin Immunol 2003, I 1 2:389-396.

33. Velasco G, Campo M, Manrique OJ, Bellou A, He H, Arestides RS, Schaub B, Perkins DL, Finn PW: Toll-like Receptor 4 or 2 Agonists Decrease Allergic Inflammation. Am J Respir Cell Mol Biol 2004

34. Alexis NE, Lay JC, Almond M, Bromberg PA, Patel DD, Peden DB: Acute LPS inhalation in healthy volunteers induces dendritic cell maturation in vivo. J Allergy Clin Immunol 2005, I I 5:345-350.

35. Tulic MK, Wale JL, Holt PG, Sly PD: Modification of the inflammatory response to allergen challenge after exposure to bacterial lipopolysaccharide. Am J Respir Cell Mol Biol 2000 22:604-6I2.

36. Backhed F, Ley RE, Sonnenburg JL, Peterson DA, Gordon Jl: Hostbacterial mutualism in the human intestine. Science 2005 , 307:1915-1920.

37. van Strien RT, Engel R, Holst O, Bufe A, Eder W, Waser M, BraunFahrlander C, Riedler J, Nowak D, von Mutius E: Microbial exposure of rural school children, as assessed by levels of $\mathrm{N}$ acetyl-muramic acid in mattress dust, and its association with respiratory health. J Allergy Clin Immunol 2004, I I 3:860-867.

38. Singh J, Schwartz DA: Endotoxin and the lung: Insight into the host-environment interaction. J Allergy Clin Immunol 2005 I I 5:330-333.

39. Dubin W, Martin TR, Swoveland P, Leturcq DJ, Moriarty AM, Tobias PS, Bleecker ER, Goldblum SE, Hasday JD: Asthma and endotoxin: lipopolysaccharide-binding protein and soluble CDI4 in bronchoalveolar compartment. Am J Physiol 1996, 270:L736-44.

40. Sigsgaard THD: On the hygiene hypothesis: Regulation down, up, or sideways? Journal of Allergy and Clinical Immunology 2005, online 23 March, 2005:.

4I. Beutler B: SHIP, TGF-beta, and endotoxin tolerance. Immunity 2004, 2 I: I34-I35.

42. Langenkamp A, Nagata K, Murphy K, Wu L, Lanzavecchia A, Sallusto $\mathrm{F}$ : Kinetics and expression patterns of chemokine receptors in human CD4+ T lymphocytes primed by myeloid or plasmacytoid dendritic cells. Eur J Immunol 2003, 33:474-482.

43. Ogura Y, Bonen DK, Inohara N, Nicolae DL, Chen FF, Ramos R, Britton H, Moran T, Karaliuskas R, Duerr RH, Achkar JP, Brant SR, Bayless TM, Kirschner BS, Hanauer SB, Nunez G, Cho JH: A frameshift mutation in NOD2 associated with susceptibility to Crohn's disease. Nature 200I, 41 I:603-606.

44. Pulendran B, Kumar P, Cutler CW, Mohamadzadeh M, Van Dyke T, Banchereau J: Lipopolysaccharides from distinct pathogens induce different classes of immune responses in vivo. J Immunol 200I, 167:5067-5076.

45. Williams LK, Ownby DR, Maliarik MJ, Johnson CC: The role of endotoxin and its receptors in allergic disease. Ann Allergy Asthma Immunol 2005, 94:323-332.

46. Erwin EA, Wickens K, Custis NJ, Siebers R, Woodfolk J, Barry D, Crane J, Platts-Mills TA: Cat and dust mite sensitivity and tolerance in relation to wheezing among children raised with high exposure to both allergens. I Allergy Clin Immunol 2005, I I 5:74-79.

47. Merchant JA, Naleway AL, Svendsen ER, Kelly KM, Burmeister LF, Stromquist AM, Taylor CD, Thorne PS, Reynolds SJ, Sanderson WT, Chrischilles EA: Asthma and farm exposures in a cohort of rural lowa children. Environ Health Perspect 2005, I I 3:350-356.

48. Chrischilles E, Ahrens R, Kuehl A, Kelly K, Thorne P, Burmeister L, Merchant J: Asthma prevalence and morbidity among rural lowa schoolchildren. J Allergy Clin Immunol 2004, I I 3:66-7I.

49. Salam MT, Li YF, Langholz B, Gilliland FD: Early-life environmental risk factors for asthma: findings from the Children's Health Study. Environ Health Perspect 2004, I I 2:760-765.

50. Schram D, Doekes G, Boeve M, Douwes J, Riedler J, Ublagger E, Mutius E, Budde J, Pershagen G, Nyberg F, Alm J, Braun-Fahrlander C, Waser M, Brunekreef $B$ : Bacterial and fungal components in house dust of farm children, Rudolf Steiner school children and reference children - the PARSIFAL Study. Allergy 2005, 60:611-618

5I. Downs SH, Marks GB, Mitakakis TZ, Leuppi JD, Car NG, Peat JK Having lived on a farm and protection against allergic diseases in Australia. Clin Exp Allergy 200I, 31:570-575.

52. Wickens K, Lane JM, Fitzharris P, Siebers R, Riley G, Douwes J, Smith $T$, Crane J: Farm residence and exposures and the risk of allergic diseases in New Zealand children. Allergy 2002, 57:1171-1179.

53. Bolte G, Bischof W, Borte M, Lehmann I, Wichmann HE, Heinrich J: Early endotoxin exposure and atopy development in infants: results of a birth cohort study. Clin Exp Allergy 2003, 33:770-776.

54. Park JH, Gold DR, Spiegelman DL, Burge HA, Milton DK: House dust endotoxin and wheeze in the first year of life. Am J Respir Crit Care Med 200I, 163:322-328

55. Liu $\mathrm{AH}$ : Endotoxin exposure in allergy and asthma: reconciling a paradox. J Allergy Clin Immunol 2002, 109:379-392.

56. Monso E, Magarolas R, Radon K, Danuser B, Iversen M, Weber C, Opravil U, Donham KJ, Nowak D: Respiratory symptoms of obstructive lung disease in European crop farmers. $\mathrm{Am} J$ Respir Crit Care Med 2000, 162: I 246-I250.

57. Kogevinas M, Anto JM, Sunyer J, Tobias A, Kromhout H, Burney P. Occupational asthma in Europe and other industrialised areas: a population-based study. European Community Respiratory Health Survey Study Group. Lancet 1999 , 353:1750-1754

58. Kronqvist M, Johansson E, Pershagen G, Johansson SG, van HageHamsten M: Risk factors associated with asthma and rhinoconjunctivitis among Swedish farmers. Allergy 1999, 54:1142-1149.

59. Vidal C, Boquete O, Gude F, Rey J, Meijide LM, Fernandez-Merino MC, Gonzalez-Quintela A: High prevalence of storage mite sensitization in a general adult population. Allergy 2004 59:40I-405. 
60. Chatzi L, Prokopakis E, Tzanakis N, Alegakis A, Bizakis I, Siafakas N, Lionis C: Allergic rhinitis, asthma, and atopy among grape farmers in a rural population in crete, Greece. Chest 2005 , I 27:372-378.

61. Hoppin JA, Umbach DM, London SJ, Alavanja MC, Sandler DP: Animal production and wheeze in the Agricultural Health Study: interactions with atopy, asthma, and smoking. Occup Environ Med 2003, 60:e3.

62. Beutler B, Rietschel ET: Innate immune sensing and its roots: the story of endotoxin. Nat Rev Immunol 2003, 3:169-176.

63. Rook GA, Martinelli R, Brunet LR, Ernst Schering Res Found Workshop 2005: Modelling gene-environment interactions in Th I and Th2-dominated diseases of laboratory animals. Anima models of $T$ cell-mediated skin diseases Ernst Schering Research Foundation Workshop, 50 (50) Springer Verlag, pp 45-68 ISBN 35402106792005.

64. Martinez FD, Holt PG: Role of microbial burden in aetiology of allergy and asthma. Lancet I999, 354 Suppl 2:SIII 2-5.

65. Michel O, Nagy AM, Schroeven M, Duchateau J, Neve J, Fondu P, Sergysels R: Dose-response relationship to inhaled endotoxin in normal subjects. Am J Respir Crit Care Med 1997, I 56: I I 57- I I 64.

66. Reed CE, Milton DK: Endotoxin-stimulated innate immunity: A contributing factor for asthma. J Allergy Clin Immunol 200I, I08:157-166.

67. Sandstrom T, Bjermer L, Rylander R: Lipopolysaccharide (LPS) inhalation in healthy subjects increases neutrophils, lymphocytes and fibronectin levels in bronchoalveolar lavage fluid. Eur Respir J 1992, 5:992-996.

68. Rizzo MC, Naspitz CK, Fernandez-Caldas E, Lockey RF, Mimica I, Sole $D$ : Endotoxin exposure and symptoms in asthmatic children. Pediatr Allergy Immunol 1997, 8: I2 I-126.

69. Litonjua AA, Milton DK, Celedon JC, Ryan L, Weiss ST, Gold DR: A longitudinal analysis of wheezing in young children: the independent effects of early life exposure to house dust endotoxin, allergens, and pets. I Allergy Clin Immunol 2002, I 1 0:736-742.

70. Arbour NC, Lorenz E, Schutte BC, Zabner J, Kline JN, Jones M, Frees K, Watt JL, Schwartz DA: TLR4 mutations are associated with endotoxin hyporesponsiveness in humans. Nat Genet 2000, 25: $|87-19|$.

7I. Werner M, Topp R, Wimmer K, Richter K, Bischof W, Wjst M, Heinrich J: TLR4 gene variants modify endotoxin effects on asthma. I Allergy Clin Immunol 2003, I I 2:323-330.

72. Michel O, LeVan TD, Stern D, Dentener M, Thorn J, Gnat D, Beijer ML, Cochaux P, Holt PG, Martinez FD, Rylander R: Systemic responsiveness to lipopolysaccharide and polymorphisms in the toll-like receptor 4 gene in human beings. J Allergy Clin Immunol 2003, I I 2:923-929.

73. Michel O, Dentener M, Corazza F, Buurman W, Rylander R: Healthy subjects express differences in clinical responses to inhaled lipopolysaccharide that are related with inflammation and with atopy. J Allergy Clin Immunol 200I, I 07:797-804.

74. Vogelzang PF, van der Gulden JW, Folgering H, Kolk JJ, Heederik D, Preller L, Tielen MJ, van Schayck CP: Endotoxin exposure as a major determinant of lung function decline in pig farmers. Am J Respir Crit Care Med 1998, I 57:15-18.

75. Monso E, Riu E, Radon K, Magarolas R, Danuser B, Iversen M, Morera J, Nowak D: Chronic obstructive pulmonary disease in neversmoking animal farmers working inside confinement buildings. Am J Ind Med 2004, 46:357-362.

76. Heinrich J, Gehring U, Douwes J, Koch A, Fahlbusch B, Bischof W, Wichmann HE: Pets and vermin are associated with high endotoxin levels in house dust. Clin Exp Allergy 200 I, 3 I: I839- 845.

77. Gereda JE, Klinnert MD, Price MR, Leung DY, Liu AH: Metropolitan home living conditions associated with indoor endotoxin levels. J Allergy Clin Immunol 200I, I07:790-796.

78. Roy SR, Schiltz AM, Marotta A, Shen Y, Liu AH: Bacterial DNA in house and farm barn dust. I Allergy Clin Immunol 2003 I I 2:57|-578.

79. Braback L, Hjern A, Rasmussen F: Trends in asthma, allergic rhinitis and eczema among Swedish conscripts from farming and non-farming environments. A nationwide study over three decades. Clin Exp Allergy 2004, 34:38-43.

80. Leynaert B, Neukirch C, Jarvis D, Chinn S, Burney P, Neukirch F: Does living on a farm during childhood protect against asthma, allergic rhinitis, and atopy in adulthood? Am J Respir Crit Care Med 200I, I 64:1829-1834.
81. Dold S, Heinrich J, Wichmann HE, Wist M: Ascaris-specific IgE and allergic sensitization in a cohort of school children in the former East Germany. J Allergy Clin Immunol 1998, I 02:4 |4-420.

82. Hoffjan S, Nicolae D, Ober C: Association studies for asthma and atopic diseases: a comprehensive review of the literature. Respir Res 2003, 4: 14.

83. Vitart V, Carothers AD, Hayward C, Teague P, Hastie ND, Campbell $H$, Wright AF: Increased level of linkage disequilibrium in rural compared with urban communities: a factor to consider in association-study design. Am J Hum Genet 2005, 76:763-772.

84. Wjst $M$ : Is the increase in allergic asthma associated with an inborn ThI maturation or with an environmental Th I trigger defect? Allergy 2004, 59:|48-150.

85. Lucock M, Yates Z: Folic acid - vitamin and panacea or genetic time bomb? Nat Rev Genet 2005, 6:235-240.

86. Koppen S, de Groot R, Neijens HJ, Nagelkerke N, van Eden W, Rumke HC: No epidemiological evidence for infant vaccinations to cause allergic disease. Vaccine 2004, 22:3375-3385.

87. Kemp T, Pearce N, Fitzharris P, Crane J, Fergusson D, St George I, Wickens $\mathrm{K}$, Beasley R: Is infant immunization a risk factor for childhood asthma or allergy? Epidemiology 1997, 8:678-680.

88. Nilsson L, Kjellman NI, Bjorksten B: Allergic disease at the age of 7 years after pertussis vaccination in infancy: results from the follow-up of a randomized controlled trial of 3 vaccines. Arch Pediatr Adolesc Med 2003, I 57: I I84- I I89.

89. Anderson HR, Poloniecki JD, Strachan DP, Beasley R, Bjorksten B, Asher MI: Immunization and symptoms of atopic disease in children: results from the International Study of Asthma and Allergies in Childhood. Am J Public Health 2001, 91: I I26-I I 29.

90. Alm JS, Swartz J, Lilja G, Scheynius A, Pershagen G: Atopy in children of families with an anthroposophic lifestyle. Lancet 1999 , 353:|485-|488.

91. Wjst M, Hoelscher B, Frye C, Wichmann HE, Dold S, Heinrich J: Early antibiotic treatment and later asthma. Eur J Med Res 200I, 6:263-27I.

92. Celedon JC, Fuhlbrigge A, Rifas-Shiman S, Weiss ST, Finkelstein JA: Antibiotic use in the first year of life and asthma in early childhood. Clin Exp Allergy 2004, 34:101 I-1016.

93. Noverr MC, Falkowski NR, McDonald RA, McKenzie AN, Huffnagle GB: Development of allergic airway disease in mice following antibiotic therapy and fungal microbiota increase: role of host genetics, antigen, and interleukin- I3. Infect Immun 2005, 73:30-38.

94. Bashir ME, Louie S, Shi HN, Nagler-Anderson C: Toll-like receptor 4 signaling by intestinal microbes influences susceptibility to food allergy. J Immunol 2004, I 72:6978-6987.

95. Hamscher G, Pawelzick HT, Sczesny S, Nau H, Hartung J: Antibiotics in dust originating from a pig-fattening farm: a new source of health hazard for farmers? Environ Health Perspect 2003, I I I:1590-1594.

96. Adler A, Tager I, Quintero DR: Decreased prevalence of asthma among farm-reared children compared with those who are rural but not farm-reared. I Allergy Clin Immunol 2005, I I 5:67-73.

97. Ball TM, Castro-Rodriguez JA, Griffith KA, Holberg CJ, Martinez FD, Wright AL: Siblings, day-care attendance, and the risk of asthma and wheezing during childhood. N Engl ] Med 2000, 343:538-543

98. Kramer U, Heinrich J, Wjst M, Wichmann HE: Age of entry to day nursery and allergy in later childhood. Lancet 1999 353:450-454.

99. Hyppönen E, Sovio U, Wjst M, Patel S, Pekkanen J, Hartikainen AL, Järvelin MR: Infant Vitamin D supplementation and allergic conditions in adulthood: Northen Finland birth cohort 1996. Ann NY Acad Sci 2004, 1 037:84-95.

100. Wjst M, Dold S: Genes, factor $\mathbf{X}$, and allergens: what causes allergic diseases? Allergy 1999, 54:757-759.

101. Feldman D, Pike J Wesley, Glorreux F H: Vitamin D. Academic Press 1997.

102. Matheu V, Back O, Mondoc E, Issazadeh-Navikas S: Dual effects of vitamin D-induced alteration of $\mathrm{TH} / \mathrm{TH} 2$ cytokine expression: enhancing IgE production and decreasing airway eosinophilia in murine allergic airway disease. J Allergy Clin Immunol 2003, I I 2:585-592.

103. Wittke A, Weaver V, Mahon BD, August A, Cantorna MT: Vitamin $D$ receptor-deficient mice fail to develop experimental allergic asthma. J Immunol 2004, I 73:3432-3436. 
104. Poon AH, Laprise C, Lemire M, Montpetit A, Sinnett D, Schurr E, Hudson TJ: Association of vitamin $D$ receptor genetic variants with susceptibility to asthma and atopy. Am J Respir Crit Care Med 2004, 170:967-973.

105. Raby BA, Lazarus R, Silverman EK, Lake S, Lange C, Wjst M, Weiss ST: Association of vitamin D receptor gene polymorphisms with childhood and adult asthma. Am J Respir Crit Care Med 2004, I 70: 1057-1065.

106. Wjst M: Genetic variants in the vitamin D receptor and childhood asthma. BMC Genetics 2005, 6:2.

107. Milner JD, Stein DM, McCarter R, Moon RY: Early infant multivitamin supplementation is associated with increased risk for food allergy and asthma. Pediatrics 2004, I | 4:27-32.

108. Holt PG, Sly PD, Martinez FD, Weiss ST, Bjorksten B, von Mutius E, Wahn U: Drug development strategies for asthma: in search of a new paradigm. Nat Immunol 2004, 5:695-698.

109. Wjst M: The triple T allergy hypothesis. Clin Dev Immunol 2004, I I:I75.

I I0. Radon K, Ehrenstein V, Praml G, Nowak D: Childhood visits to animal buildings and atopic diseases in adulthood: an agedependent relationship. Am J Ind Med 2004, 46:349-356.

I I I. Kersting M: Ernährung des gesunden Säuglings, Lebensmittelund mahlzeitenbezogene Empfehlungen. Monatsschr Kinderheilkd 200I, I49:4-10.

I I2. Kersting M, Alexy U: Vitamin and mineral supplements for the use of children on the German market: products, nutrients, dosages. Ann Nutr Metab 2000, 44:125-128.

I 13. Barnes M, Cullinan P, Athanasaki P, MacNeill S, Hole AM, Harris J, Kalogeraki S, Chatzinikolaou M, Drakonakis N, Bibaki-Liakou V, Newman Taylor AJ, Bibakis I: Crete: does farming explain urban and rural differences in atopy? Clin Exp Allergy 200I, 31: I822-I828.

I 14. Hugot JP, Alberti C, Berrebi D, Bingen E, Cezard JP: Crohn's disease: the cold chain hypothesis. Lancet 2003, 362:20I2-20I5.

II5. Brooke OG, Butters F, Wood C: Intrauterine vitamin D nutrition and postnatal growth in Asian infants. $\mathrm{Br}$ Med J (Clin Res Ed) 1981, 283:1024.

I 16. Sankaran K, Papageorgiou A, Ninan A, Sankaran R: A randomized, controlled evaluation of two commercially available human breast milk fortifiers in healthy preterm neonates. J Am Diet Assoc 1996, 96: I |45-1 |49.

I 17. Du X, Zhu K, Trube A, Zhang Q, Ma G, Hu X, Fraser DR, Greenfield $\mathrm{H}$ : School-milk intervention trial enhances growth and bone mineral accretion in Chinese girls aged $10-12$ years in Beijing. Br J Nutr 2004, 92: I59-I68.

I I8. Burne TH, McGrath J], Eyles DW, Mackay-Sim A: Behavioural characterization of Vitamin D receptor knockout mice. Behav Brain Res 2005, I 57:299-308.

119. Liu Y, Albertsson-Wikland K, Karlberg J: Long-term consequences of early linear growth retardation (stunting) in Swedish children. Pediatr Res 2000, 47:475-480.

120. Eduard W, Omenaas E, Bakke PS, Douwes J, Heederik D: Atopic and non-atopic asthma in a farming and a general population. Am J Ind Med 2004, 46:396-399.

12I. Bolte G, Schmidt M, Maziak W, Keil U, Nasca P, von Mutius E, Weiland SK: The relation of markers of fetal growth with asthma allergies and serum immunoglobulin $E$ levels in children at age 5-7 years. Clin Exp Allergy 2004, 34:38I-388.

122. Leadbitter P, Pearce N, Cheng S, Sears MR, Holdaway MD, Flannery EM, Herbison GP, Beasley R: Relationship between fetal growth and the development of asthma and atopy in childhood. Thorax 1999, 54:905-910.

123. Beasley R, Leadbitter P, Pearce N, Crane J: Is enhanced fetal growth a risk factor for the development of atopy or asthma? Int Arch Allergy Immunol 1999, I I 8:408-4I0.

124. Gregory A, Doull I, Pearce N, Cheng S, Leadbitter P, Holgate S, Beasley R: The relationship between anthropometric measurements at birth: asthma and atopy in childhood. Clin Exp Allergy 1999, 29:330-333.

125. Katz KA, Pocock S], Strachan DP: Neonatal head circumference, neonatal weight, and risk of hayfever, asthma and eczema in a large cohort of adolescents from Sheffield, England. Clin Exp Allergy 2003, 33:737-745.

126. Beser E, Cakmakci T: Factors affecting the morbidity of vitamin D deficiency rickets and primary protection. East Afr Med J |994, $71: 358-362$
127. Wayse V, Yousafzai A, Mogale K, Filteau S: Association of subclinical vitamin $D$ deficiency with severe acute lower respiratory infection in Indian children under 5 y. Eur J Clin Nutr 2004, 58:563-567.

128. Najada AS, Habashneh MS, Khader M: The frequency of nutritional rickets among hospitalized infants and its relation to respiratory diseases. J Trop Pediatr 2004, 50:364-368.

129. Sachan A, Gupta R, Das V, Agarwal A, Awasthi PK, Bhatia V: High prevalence of vitamin $D$ deficiency among pregnant women and their newborns in northern India. Am J Clin Nutr 2005, 81: 1060-1064.

130. Griffin MD, Lutz W, Phan VA, Bachman LA, McKean DJ, Kumar R: Dendritic cell modulation by I alpha,25 dihydroxyvitamin D3 and its analogs: a vitamin $D$ receptor-dependent pathway that promotes a persistent state of immaturity in vitro and in vivo. Proc Natl Acad Sci U S A 200I, 98:6800-6805.

131. Lyakh LA, Sanford M, Chekol S, Young HA, Roberts AB: TGF-\{beta\} and Vitamin D3 Utilize Distinct Pathways to Suppress IL- I 2 Production and Modulate Rapid Differentiation of Human Monocytes into CD83+ Dendritic Cells. J Immunol 2005, I 74:206 I-2070.

132. Kuipers H, Hijdra D, De Vries VC, Hammad H, Prins JB, Coyle AJ, Hoogsteden HC, Lambrecht BN: Lipopolysaccharide-induced suppression of airway Th2 responses does not require IL- I 2 production by dendritic cells. J Immunol 2003, I 7 I:3645-3654.

133. Pramanik R, Asplin JR, Lindeman C, Favus MJ, Bai S, Coe FL: Lipopolysaccharide negatively modulates vitamin $D$ action by downregulating expression of vitamin D-induced VDR in human monocytic THP-I cells. Cell Immunol 2004, 232(( I-2)):I37-43.
Publish with Bio Med Central and every scientist can read your work free of charge

"BioMed Central will be the most significant development for disseminating the results of biomedical research in our lifetime. "

Sir Paul Nurse, Cancer Research UK

Your research papers will be:

- available free of charge to the entire biomedical community

- peer reviewed and published immediately upon acceptance

- cited in PubMed and archived on PubMed Central

- yours - you keep the copyright

Submit your manuscript here:

http://www.biomedcentral.com/info/publishing_adv.asp
BioMedcentral 